tiếp tục các nghiên cứu điều trị trong thời gian dài hơn để đánh giá được kết quả toàn diện.

\section{KẾT LUẬN}

Nghiên cứu với 300 người bệnh TVĐĐCSTL được áp dụng quy trình quản lý điều trị của chúng tôi đã đạt kết quả khả quan. Sau 30 ngày điều trị, các chỉ số lâm sàng đánh gía người bệnh đều tốt. Tình trạng chung của người bệnh sau 30 ngày điều trị có kết quả điều trị rất tốt đạt $69,7 \%$; kết quả tốt đạt 26,0\%, kết quả trung bình đạt 4,3\%, không có người bệnh nào kết quả điều trị kém. Như vậy việc quản lý điều trị người bệnh TVĐĐCSTL theo quy trình chúng tôi xây dựng nên tiếp tục duy trì và mở rộng áp dụng tại khoa phục hồi chức năng bệnh viện đa khoa tỉnh Thanh Hoá.

\section{TÀI LIÊU THAM KHẢO}

1. Hồ Hữu Lương (2001), Đau thắt lưng và thoát vị đĩa đệm, Nhà xuất bản Y học, Hà Nội.

2. Khoa $Y$ hoc cổ truyên; Trường Đai hoc $Y$ Hà Nôi (2002), Băi giảng Y học cổ truyền tập II, Nhà xuất bản $Y$ học, Hà Nội.

3. Wu Guang-Wei; Yang Xiang-Yu (2007), Clinical report treatment of 89 cases of lumbar intervertebral disc herniation with acupuncture; Chinese acupuncture and moxibustion, 4(4) p 230-247.

4. K. W. Faiz (2014), "VAS-Visual Analog Scale", Tidsskr Nor Laegeforen, 134(3), p. 323.

5. Amor B; Rvel M; Dougados M (1985), Traitment des conflits discogradinculaive par infection intradiscale daprotinine, Medicine et armies, 751-754.

6. Trân Thi Minh Ouvên (2011). Đánh qiá tác dunq điêu tri thoát vi đĩa đêm CSTL bằna phươna pháp điên châm kết hở kéo aiãn cột sống. Luận văn bác sỹ nội trú. ĐH Y Hà Nội.

7. Nguyến Văn Hưng, Pham Thị Xuân Mai (2018), Hiệu quả điều trị đạu thắt lưng do thoái hoá cột sống bằng điện mãng châm kết hợp hài thuốc. Tap chí Y Dược học - Trường Đại học Y Dược Huể - Tập 8, số 5 - tháng 10/2018.

\title{
PHÂN TÍCH VIỆC THỰC HIỆN KẾT QUẢ ĐẦU THẦU THUỐC TẬP TRUNG CỦA CÁC BỆNH VIỆN TUYẾN TİNH TẠI VĨNH PHÚC NĂM 2017
}

\section{Lã Thị Quỳnh Liên', Nguyễn Thị Kiều Anh ${ }^{2}$}

\section{TÓM TẮT}

Đấu thầu thuốc tập trung tại Sở Y tế giúp tiết kiệm thời gian, đảm bảo giá thuốc hợp lý, công bằng, tuy nhiên cũng có nhiều khó khăn trong việc xác định nhu cầu sử dụng thuốc sát với thực tế và trong thực hiện kết quả trúng thầu của các đ̛ơn vị khám chữa bệnh. Đây là nghiên cứu đầu tiên được thực hiện tại Sở y tế Vinh Phúc nhằm đánh giá viêc thực hiện kết quả trúng thâu của các bệnh viện tuyến tỉnh trên địa bàn, từ đó đưa ra giải pháp nhằm khắc phục những tồn tại, góp phần nâng cao hiệu quả của công tác đấu thầu thuốc tập trung. Phương pháp nghiên cứu: Thiết kế mô tả cắt ngang, hồi cứu các báo cáo thực hiện kết quả trúng thầu của 06 bệnh viện tuyến tỉnh tại Sở Y tế Vính Phúc năm 2017. Thống kê mô tả: tính tỷ lệ phần trăm đối với các biến phân loại. Kết quả: Bệnh viện Tâm thần có tỷ lệ số khoản thực hiện cao nhất $(100 \%)$ nhưng giá trị thực hiện thấp nhất $(46,9 \%)$. Bệnh viên đa khoa khu vực Phúc Yên có tỷ lẹ giá trị thực hiển cao nhất $(67,5 \%)$, và tỷ lệ số khoản thực hiện xểp thứ 2 (82,3\%). Bệnh viện Phục hồi chức năng có tỷ lệ số khoản thực hiện thấp nhất $(45,5 \%)$. Gói thầu thuốc Generic có tỷ lệ số khoản thực hiên không đạt $80 \%$ cao nhất $(73,5 \%)$. Trong 16 thuốc

${ }^{1}$ Trường Đại học Dược Hà Nội

${ }^{2}$ Sở Y tế vinh Phúc

Chịu trách nhiệm chính: Lã Thị Quỳnh Liên

Email: lienltq@hup.edu.vn

Ngày nhận bài: 5.01.2021

Ngày phản biện khoa học: 2.3.2021

Ngày duyệt bài: 12.3.2021 thực hiện vượt $120 \%$ có 8 thuốc có nguyên nhân khách quan, 8 thuốc thực hiện không đúng quy định khi vẫn còn số lượng thuốc trúng thầu khác thay thế. Kết luận: Các bệnh viện tuyến tỉnh trên địa bàn tỉnh Vĩnh Phúc năm 2017 có tỷ lệ thực hiện kết quả trúng thâu thấp. Trong số các thuốc thực hiện vượt $120 \%$, $50 \%$ số thuốc thực hiện không đúng quy định khi vẫn còn số lượng thuốc trúng thầu khác thay thế.

Từ khoá: Đấu thầu tập trung, Vĩnh Phúc

\section{SUMMARY}

\section{IMPLEMENTATION OF DRUG BIDDING RESULTS AT PROVINCIAL HOSPITALS IN VINH PHUC IN 2017}

Concentrated drug bidding at department of health saves time, ensures reasonable prices. However, there are also many difficulties in identifying needs and in implementing bidding results. This study aimed to evaluate the implementation of bidding result at provincial hospitals in Vinh Phuc. Methods: crosssectional sduty; data were collected from reports on implementing bidding results of 06 provincial hospitals at Vinh Phuc Department of Health in 2017. Percentages were calculated for categorical variables. Results: The Psychiatric Hospital had the highest implementing rate in terms of drug items (100\%), but the lowest implementing rate in terms of money value (46.9\%). Phuc Yen Regional General Hospital has the highest rate of money value implementation $(67.5 \%)$, and the second rate in terms of drug items (82.3\%). The Rehabilitation Hospital had the lowest rate of drug item implementation, accounting for $45.5 \%$. Generic drug bidding package had the highest rate of 
implementation not reaching $80 \%$, accounting for $73.5 \%$. Of the 16 drugs that exceed $120 \%, 8$ drugs had objective reasons, the other drugs were not complying with regulations while there were still quantity of other drugs to replace. Conclusion: The provincial hospitals in Vinh Phuc province in 2017 had low rates of implementing bidding result. Among the drugs that exceeded $120 \%, 50 \%$ of the drugs did not comply with the regulations while there were still the number of other drugs to replace.

Key words: Concentrated drug bidding, Vinh Phuc

\section{I. ĐĂT VẤN ĐỀ}

Trong quản lý cung ứng thuốc, mua sắm thuốc là giai đoạn quan trọng giúp phục vụ hiệu quả hoạt động khám chữa bệnh [8]. Từ năm 2005, khi thông tư số 20/2005/TTLT-BYT-BTC hướng dẫn thực hiện đấu thầu cung ứng thuốc trong các cơ sở y tế công lập ra đời, nhiều địa phương đã tổ chức đấu thầu thuốc tập trung tại Sở $Y$ tế cho các cơ sở y tế trên địa bàn. Đấu thầu thuốc tập trung có ưu điểm là tiết kiệm thời gian cho các đơn vị khám chữa bệnh, đảm bảo thống nhất giá thuốc trúng thầu trên địa bàn tỉnh. Tuy nhiên, đấu thầu thuốc tập trung cũng có hạn chế là cán bộ công chức Sở Y tế có thể không nắm rõ nhu cầu sử dụng thuốc của các đơn vị khám chữa bệnh, để có định hướng phân tích và xử lý phù hợp trong quá trình lập, thẩm định kế hoạch lựa chọn nhà thâu $[5,6]$.

Việc thực hiện kết quả đấu thầu thuốc tập trung cũng gặp nhiều khó khăn. Sở $Y$ tế phải thường xuyên giám sát việc thực hiện kết quả trúng thâu, và phải có các giải pháp kịp thời khi có bất cập. Về phía nhà thầu, việc cung cấp hàng cùng lúc cho nhiêu cơ sở khác nhau sẽ phát sinh chi phí trong việc vận chuyển, thanh toán và giao nhâan giấy tờ. Có trường hợp nhà thầu sẵn sàng chấp nhận mất tiền bảo lãnh thực hiện hợp đồng và khồng thực hiện cung ứng thuốc theo kết quả trúng thầu dẩn đến thiếu thuốc. Các cơ sở y tế phải đề phòng trường hợp nhà thầu không thực hiện hợp đồng, chậm cung ứng hoặc hết hàng, dự phòng thuốc sử dụng trong thời gian đã hết thầu cũ nhưng chưa có kết quả thâuu mới, dự phòng trường hợp nhà thầu dừng cung ứng khi bệnh viện hết tiền quỹ không thanh toán đúng hạn cho nhà thầu. Do đó, danh mục thuốc các cơ sở y tế gửi đớn vị đấu thầu tập trung nhiều khi chưa sát với thực tế [7].

Vĩnh Phúc là môt trong số ít các tỉnh trong cả nước thực hiện đấu thầu thuốc tập trung sớm, ổn định từ năm 2005 tại Sở Y tế. Đây là nghiên cứu đầu tiên được thực hiện tại Sở y tế Vinnh Phúc nhằm đánh giá việc thực hiện kết quả trúng thầu của các bệnh viện tuyến tỉnh trên địa bàn, từ đó đưa ra giải pháp nhằm khắc phục những tồn tại, khó khăn, góp phần nâng cao hiệu quả của công tác đâu thầu thuốc tập trung tại Sở Y tế Vĩnh Phúc.

\section{II. ĐỐI TƯợNG VÀ PHƯƠNG PHÁP NGHIÊN CứU}

Nghiên cứu sử dụng thiết kễ mô tả cắt ngang, hồi cứu các báo cáo thực hiện kết quả trúng thầu của 06 bệnh viện tuyến tỉnh tại Sở $Y$ tế Vinnh Phúc năm 2017 đối với 3 gói thầu: gói thầu thuốc generic; gói thầu thuốc biệt dược gốc hoặc tương đương điều trị; gói thầu thuốc cổ truyền, thuốc dược liệu. Tổng số có 626 khoản mục thuốc thực hiện.

Số liệu nghiên cứu sau khi thu thập, được nhập và xử lý trên phần mềm Microsoft Excel 2013. dụng phương pháp thống kê mô tả: tính tỷ lệ đối với biến phân loại.

\section{KẾT QUẢ NGHIÊN CỨU}

3.1. Thực hiện kết quả trúng thâu theo từng bệnh viện. Bệnh viện Tâm thần có tỷ lệ số khoản thực hiện cao nhất (100\%) nhưng giá trị thực hiện lại thấp nhất (46,9\%). Bệnh viện đa khoa khu vực Phúc Yên có tỷ lệ giá trị thực hiện cao nhất $(67,5 \%)$, và tỷ lệ số khoản thực hiện xếp thứ $2(82,3 \%)$. Bệnh viện Sản nhi và Bệnh viện $Y$ học cổ truyền có tỷ lệ số khoản thực hiện gần bằng nhau $(54,5 \%$ và $54,2 \%)$ nhưng Bệnh viện Sản nhi có giá trị thực hiện lớn hơn $(53,2 \%)$ Bểnh viện $Y$ học cổ truyền $(47,6 \%)$. Bệnh viện Phục hồi chức năng có tỷ lệ số khoản thực hiện thấp nhất chiếm $45,5 \%$, giá trị thực hiện cũng thấp hơn một nửa so với giá trị trúng thâu (48,5\%) (Bảng 3.1).

Bảng 3.1. Tỷ lệ thực hiện kêt quả trúng thầu theo từng bệnh viện

\begin{tabular}{|c|c|c|c|c|c|c|c|}
\hline \multirow{2}{*}{ STT } & \multirow{2}{*}{ Tên bệnh viện } & \multicolumn{3}{|c|}{ Số khoản mục } & \multicolumn{3}{c|}{ Giá trị (triệu đồng) } \\
\cline { 3 - 8 } & $\begin{array}{c}\text { Trúng } \\
\text { thầu }\end{array}$ & $\begin{array}{c}\text { Thực } \\
\text { hiện }\end{array}$ & $\begin{array}{c}\text { Tỷ lệe } \\
\text { (\%) }\end{array}$ & $\begin{array}{c}\text { Trúng } \\
\text { thầu }\end{array}$ & Thực hiện & $\begin{array}{c}\text { Tỷ lệ } \\
\text { (\%) }\end{array}$ \\
\hline 1 & Bệnh viện đa khoa Tỉnh & 553 & 403 & 72,9 & $155.429,5$ & 85.478 & 55,0 \\
\hline 2 & $\begin{array}{c}\text { Bệnh viện đa khoa khu vực } \\
\text { Phúc Yên }\end{array}$ & 413 & 340 & 82,3 & $133.145,5$ & 89.810 & 67,5 \\
\hline 3 & Bệnh viện Sản nhi & 341 & 186 & 54,5 & 39.575 & 21.047 & 53,2 \\
\hline
\end{tabular}




\begin{tabular}{|l|c|c|c|c|c|c|c|}
\hline 4 & Bệnh viện Y học cố truyền & 240 & 130 & 54,2 & 6.029 & 2.871 & 47,6 \\
\hline 5 & Bệnh viện Phục hồi chức năng & 292 & 133 & 45,5 & 5.355 & 2.598 & 48,5 \\
\hline 6 & Bệnh viện Tâm thần & 39 & 39 & 100,0 & 119 & 56 & 46,9 \\
\hline & Tống cộng & $\mathbf{8 2 3}$ & $\mathbf{6 2 6}$ & $\mathbf{7 6 , 1}$ & $\mathbf{3 3 9 . 6 5 3}$ & $\mathbf{2 0 1 . 8 6 0}$ & $\mathbf{5 9 , 4}$ \\
\hline
\end{tabular}

3.2 Cơ cấu số khoản theo tỷ lệ thực hiện tại các bệnh viện

Tỷ lệ thuốc chưa thực hiện được $80 \%$ giá trị của các bệnh viện tuyến tỉnh trên địa bàn tỉnh Vính Phúc năm 2017 cao, chiếm 68,8\% tổng số khoản trúng thâu: cao nhất ở Bệnh viện Tâm thần $(71,8 \%)$, thấp nhất là Bệnh viện Y học cố truyền (44,6\%). Tỷ lệ thuốc thực hiện được $80 \%-120 \%$ giá trị trúng thâuu thấp, chỉ có $28,6 \%$ tổng số khoản trúng thầu. Tỷ lệ thuốc thực hiện vượt $120 \%$ giá trị trúng thầu chiếm 2,6\% tổng số khoản trúng thầu (Bảng 3.2).

Bảng 3.2. Cơ cấu số khoản theo tỷ lệ thực hiện tại các bệnh viện

\begin{tabular}{|c|c|c|c|c|c|c|c|c|}
\hline \multirow[b]{2}{*}{ STT } & \multirow[b]{2}{*}{ Tên bệnh viện } & \multicolumn{7}{|c|}{ Số khoản thực hiện } \\
\hline & & $80 \%$ & $\begin{array}{l}\text { Tỷ lề } \\
(\%)\end{array}$ & $\begin{array}{l}80 \%- \\
120 \%\end{array}$ & $\begin{array}{l}\text { Tỷ lề } \\
(\%)\end{array}$ & ${ }_{120 \%}^{>}$ & $\begin{array}{l}\text { Tỷ lệ́ } \\
(\%)\end{array}$ & Tổng \\
\hline 1 & Bệnh viện đa khoa tỉnh & 231 & 57,3 & 159 & 39,5 & 13 & 3,2 & 403 \\
\hline 2 & $\begin{array}{l}\text { Bệnh viện đa khoa khu vực } \\
\text { Phúc Yên }\end{array}$ & 189 & 55,6 & 116 & 42,4 & 8 & 2,1 & 340 \\
\hline 3 & Bệnh việ & 126 & & 57 & 30,6 & 3 & 1,6 & 86 \\
\hline 4 & Bệnh viện Y h & 58 & 44,6 & 69 & 53,1 & 3 & 2,3 & 130 \\
\hline 5 & Bệnh viện Phục hồi chức năng & 70 & 52,6 & 63 & 47,4 & 0 & 0,0 & 133 \\
\hline 6 & Bênh viên T & 28 & & 11 & 28,2 & 0 & 0,0 & 39 \\
\hline & Tống & 431 & 68,8 & 179 & 28,6 & 16 & 2,6 & 626 \\
\hline
\end{tabular}

3.3 Thực hiện kết quả trúng thâuu theo gói thầu, nhóm kỹ thuật

Trong 3 gói thầu: Gói thầu thuốc biệt dược gốc có tỷ lệ số khoản thực hiện cao nhất $(89,2 \%)$, sau đó đến Gói thầu thuốc cổ truyên, thuốc dược liệu $(77,5 \%)$ và thấp nhất là Gói thầu thuốc Generic $(74,4 \%)$. Tuy nhiên tỷ lệ giá trị thực hiện của Gói thầu thuốc biệt dược gốc lại thấp nhất (chỉ đạt $53,4 \%)$, Gói thầu thuốc Generic đạt $60,3 \%$, cao nhất là Gói thầu thuốc cổ truyển, thuốc dược liệu $(75,6 \%)$. Không có gói thầu nào đạt tỷ lệ giá trị sử dụng lớn hơn $80 \%$ (Bảng 3.3).

Bảng 3.3: Tỷ lệ thực hiện kềt quả trúng thầu theo gói thầu, nhóm kỹ thuật

\begin{tabular}{|c|c|c|c|c|c|c|}
\hline \multirow{2}{*}{ Tên gói thâu } & \multicolumn{3}{|c|}{ Số khoản mục } & \multicolumn{3}{c|}{ Giá trị (đồng) } \\
\cline { 2 - 7 } & $\begin{array}{c}\text { Trúng } \\
\text { thâuu }\end{array}$ & $\begin{array}{c}\text { Thực } \\
\text { hiện }\end{array}$ & $\begin{array}{c}\text { Tỷ lệ } \\
\text { \%o }\end{array}$ & $\begin{array}{c}\text { Trúng } \\
\text { thâuu }\end{array}$ & $\begin{array}{c}\text { Thực } \\
\text { hiện }\end{array}$ & $\begin{array}{c}\text { Tỷ lệ } \\
\text { \% }\end{array}$ \\
\hline Thuốc Generic & 700 & 521 & 74,4 & 285.301 & 172.012 & 60,3 \\
\hline Thuốc biê̂t dược gốc & 83 & 74 & 89,2 & 50.674 & 27.068 & 53,4 \\
\hline Thuốc cố truyền, thuốc dược liệu & 40 & 31 & 77,5 & 3.678 & 2.780 & 75,6 \\
\hline Tống cộng & $\mathbf{8 2 3}$ & $\mathbf{6 2 6}$ & $\mathbf{7 6 , 1}$ & $\mathbf{3 3 9 . 6 5 3}$ & $\mathbf{2 0 1 . 8 6 0}$ & $\mathbf{5 9 , 4}$ \\
\hline
\end{tabular}

3.4 Cơ cấu số khoản của từng gói thâu, nhóm kỹ thuật theo tỷ lệ thực hiện

Gói thầu thuốc Generic có tỷ lệ số khoản thực hiện không đạt $80 \%$ cao nhất $(70,6 \%)$, tiếp theo là Gói thâuu thuốc biệt dược gốc $(64,9 \%)$ và thẩp nhất là Gói thầu thuốc cổ truyền, thuốc dược liệu $(48,4 \%)$. Tỷ lệ số khoản thực hiện vượt $120 \%$ ở hai Gói thầu thuốc Generic và Gói thầu thuốc biệt dược gốc tương đương nhau (2,7\%), Gói thâu thuốc cổ truyền, thuốc dược liệu không có thuốc thực hiện vượt 120\% (Bảng 3.4).

Bảng 3.4. Cơ câu thực hiện của từng gói thầu theo tỷ lệ thực hiện

\begin{tabular}{|c|c|c|c|c|c|c|c|c|}
\hline \multirow[b]{2}{*}{ STT } & \multirow[b]{2}{*}{$\begin{array}{l}\text { Tên gói thâu, } \\
\text { nhóm kỹ thuật }\end{array}$} & \multicolumn{6}{|c|}{ Số khoản thực hiên } & \multirow[b]{2}{*}{ Tổng } \\
\hline & & $<80 \%$ & $\begin{array}{l}\text { Tỷ lệ } \\
(\%)\end{array}$ & $\begin{array}{l}80 \%- \\
120 \%\end{array}$ & $\begin{array}{l}\text { Tý lề } \\
(\%)\end{array}$ & $>120 \%$ & $\begin{array}{l}\text { Tỷ lệ } \\
(\%)\end{array}$ & \\
\hline 1 & Thuốc Generic & 368 & 70,6 & 139 & 26,7 & 14 & 2,7 & 521 \\
\hline 2 & Thuốc biệt dược gốc & 48 & 64,9 & 24 & 32,4 & 2 & 2,7 & 74 \\
\hline 3 & $\begin{array}{l}\text { Thuốc cố truyên, } \\
\text { thuốc dược liệu }\end{array}$ & 15 & 48,4 & 16 & 51,6 & 0 & 0,0 & 31 \\
\hline & Tống cộng & 431 & 68,8 & 179 & 28,6 & 16 & 2,6 & 626 \\
\hline
\end{tabular}

3.5 Phân tích nguyên nhân số khoản thực hiện vượt quá $120 \%$ kết quả trúng thâu. Các thuốc thực hiện vượt 120\% số lượng đều là các thuốc thiết yếu, dùng để điều trị chính, không có thuốc hố trợ điều trị và giá trị mua vượt $120 \%$ cũng rất nhỏ (Bảng 3.5). 
Bảng 3.5. Các thuốc thực hiện vượt quá $120 \%$ kêt quả trúng thầu

\begin{tabular}{|c|c|c|}
\hline $\begin{array}{c}\text { Tên hoạt chất, nồng độ } \\
\text { hàm lượng, đường } \\
\text { dùng }\end{array}$ & $\begin{array}{c}\text { Gói } \\
\text { thâu / } \\
\text { nhóm kỹ } \\
\text { thuật }\end{array}$ & $\begin{array}{l}\text { Tỷ lệ } \\
\text { thưứ } \\
\text { hiệ̂n } \\
(\%)\end{array}$ \\
\hline $\begin{array}{c}\text { Isoflurane } 100 \mathrm{ml} \text {, gây mê } \\
\text { qua đường hô hấp }\end{array}$ & Generic 1 & 150 \\
\hline $\begin{array}{c}\text { Paracetamol } 200 \mathrm{mg} / 20 \mathrm{ml} \text {, } \\
\text { truyền }\end{array}$ & Generic 2 & 132 \\
\hline Cefdinir $125 \mathrm{mg} / 5 \mathrm{ml}$, uống & Generic 3 & 139 \\
\hline Exemestan $25 \mathrm{mg}$, uống & Generic 1 & 120,14 \\
\hline $\begin{array}{c}\text { Levodopa } \\
\text { 100mg+Carbidopa 25mg + } \\
\text { Entacapon 200mg, uống }\end{array}$ & Generic 1 & 122 \\
\hline $\begin{array}{l}\text { Gelatin succinyl } 20 \mathrm{~g}+\text { natri } \\
\text { clorid } 3,505 \mathrm{~g}+\text { natri } \\
\text { hydroxyd } 0,68 \mathrm{~g} / 500 \mathrm{ml} \\
\text { truyên } \\
\end{array}$ & Generic 2 & 124 \\
\hline Amlodipine 5mg; uống & Generic 1 & 130 \\
\hline Bisoprolol 2,5mg; uống & Generic 2 & 125 \\
\hline Metoprolol 50mg; uống & Generic 1 & 150 \\
\hline $\begin{array}{c}\text { Acid acetylsalicylic } 100 \mathrm{mg} ; \\
\text { uống }\end{array}$ & Generic 3 & 128 \\
\hline $\begin{array}{c}\text { Nhôm oxyd 400mg+ } \\
\text { Magnesium hydroxyd } \\
800,4 \mathrm{mg}+\text { Simethicone } \\
80 \mathrm{mg} ; \text { uống }\end{array}$ & Generic 2 & 145 \\
\hline Esomeprazol 20mg, uống & Generic 1 & 131 \\
\hline Esomeprazol 40mg, uống & \begin{tabular}{|l} 
Biệt dược \\
gốc
\end{tabular} & 210 \\
\hline Sucralfat $1 \mathrm{~g} / 15 \mathrm{~g}$; uống & Generic 3 & 123 \\
\hline $\begin{array}{l}\text { Alverin citrat } 60 \mathrm{mg}+ \\
\text { Simethicon } 80 \mathrm{mg} ; \text { uống }\end{array}$ & Generic 3 & 159 \\
\hline Insulin 100UI/ml; tiêm & $\begin{array}{l}\text { Biệt dược } \\
\text { gốc }\end{array}$ & 127 \\
\hline
\end{tabular}

Thuốc Isofluran 100ml (Piramal-Mỹ) thực hiện $150 \%$ số lượng trúng thầu do chỉ có mặt hàng thuốc Isofluran $100 \mathrm{ml}$ (Baxter-Mỹ) tương tự thay thế, nhưng thuốc này cũng đã thực hiện được $120 \%$. Thuốc Paracetamol $200 \mathrm{mg} / 20 \mathrm{ml}$ thực hiện $132 \%$ : trong danh mục trúng thầu có 3 thuốc có thể thay thế đều có văn bản không cung ứng được hoặc dừng cung ứng với lý do không có hàng từ phía nhà sản xuất: Paracetamol $900 \mathrm{mg} / 90 \mathrm{ml}$ (thực hiện 68\%), Paracetamol $500 \mathrm{mg} / 50 \mathrm{ml}$ (thực hiện $30 \%$ ), Paracetamol $1000 \mathrm{mg} / 100 \mathrm{ml}$ (thực hiện 0\%). Thuốc Levodopa $100 \mathrm{mg}+$ Carbidopa $25 \mathrm{mg}+$ Entacapon $200 \mathrm{mg}$ thực hiện $122 \%$, là thuốc điều trị Parkinson, trong danh muc không có thuốc thay thế, và tỷ lệ vượt cững rất nhỏ.Thuốc Gelatin succinyl $20 \mathrm{~g}+$ natri clorid $3,505 \mathrm{~g}+$ natri hydroxyd $0,68 \mathrm{~g} / 500 \mathrm{ml}$, thực hiện $124 \%$, mặt hàng thuốc trên sử dụng trong cấp cứu do mất máu nhiều, không có thuốc thay thế. Hai mặt hàng thuốc Bisoprolol 5mg Nhóm 1 thực hiện $125 \%$, Metoprolol $50 \mathrm{mg}$ thực hiện $150 \%$, đây là 2 thuốc hạ huyết áp thuộc nhóm chẹn beta chọn lọc, không còn thuốc Generic thay thế, trong danh mục chỉ còn thuốc biệt dược gốc. Acid acetyl salicylic $100 \mathrm{mg}$ (Traphaco) thực hiên $128 \%$, trong danh mục chỉ có 1 thuốc thay thế Acid acetyl salicylic $100 \mathrm{mg}$ (Sao kim), thuốc này mới thực hiên được $51 \%$ nhưng nhà thầu có văn bản dừng cung ứng do lỗi của dây truyền sản xuất.

Các thuốc còn lại thực hiện chưa đúng quy định khi mua vượt quá $120 \%$ trong khi vẫn còn các thuốc trúng thầu khác có thể thay thế.

\section{BÀN LUÂ̂N}

Theo hiểu biết của tác giả, đây là nghiên cứu duy nhất đến thời điểm hiện tại phân tích việc thực hiện kết quả đấu thâuu thuốc tập trung của các bệnh viện tuyến Tỉnh tại Vĩnh Phúc. Kết quả nghiên cứu chỉ ra thực trang và một số bất cập trong thực hiện kết quả đấu thâu, là căn cứ để các bệnh viện cải thiện hoạt động sử dụng thuốc, xây dựng nhu cầu sử dụng thuốc sát với thực tế, giúp các nhà quản lý có giải pháp phù hợp trong triển khai kế hoạch đấu thầu.

4.1. Thực hiện kết quả trúng thâu theo từng bệnh viện. Các bệnh viện tuyến tỉnh trên địa bàn tỉnh Vĩnh Phúc năm 2017 có tỷ lệ số khoản thực hiện và giá trị thực hiện thấp: tổng số khoản thực hiện được $76,1 \%$ so với tổng số khoản trúng thầu, tổng giá trị thực hiện chiếm 59,4\% so với tổng giá trị trúng thầu, không đạt tỷ lệ thực hiện $80 \%$ số lượng trúng thầu do Sở Y tế quy định trong Văn bản hướng dẫn thực hiện kết quả lựa chọn nhà thầu thuốc năm 2017. Kết quả này thấp hơn so với tỷ lệ thực hiện tại một số địa phương như: Sở Y tế Hà Giang năm 2016: Tỷ lệ số khoản thực hiện đạt 90,7\%, tỷ lệ giá trị thực hiện kết quả trúng thẩu là $74,23 \%$ [3]; Sở Y tế Hà Nội năm 2016: Tỷ lệ số khoản thực hiện kết quả trúng thầu là $85 \%$, tỷ lệ giá trị thực hiện kết quả trúng thầu là $75 \%$ [4].

Bệnh viên đa khoa khu vực Phúc Yên có số khoản thực hiện và giá trị thực hiện cao nhất (lần lượt là $82,3 \%$ và $67,5 \%$ ). Bệnh viện Phục hồi chức năng có tỷ lệ số khoản thực hiện thấp nhất chiếm $45,5 \%$, như vây là hơn môt nửa số khoản bệnh viện dự trù, trúng thầu nhưng không thực hiện. Đối với Bệnh viện tâm thần có số khoản thực hiện $100 \%$ là do mô hình bệnh tật của Bệnh viện hầu như không thay đổi qua các năm. Tuy nhiên giá trị thực hiện của Bệnh viện 
Tâm thần lại thấp nhất do trên kế hoạch bênh viện được giao 120 gường bệnh nhưng thực tế công suất sử dụng giường bệnh của bệnh viện trong năm 2017 chỉ đạt $64 \%$.

4.2 Cơ cấu số khoản theo tỷ lê thực hiện tại các bệnh viện. Tỷ lệ khoản mục thuốc khổng thực hiện hoặc thực hiện không đạt $80 \%$ lớn ở cả 06 bệnh viện (đa số trên $50 \%$ ). Tuy nhiên, trong báo cáo thực hiện kết quả trúng thầu của các bệnh viện chưa được phân loại nguyên nhân tỷ lệ thực hiện thấp. Mặc dù Sở Y tế đã có hướng dẫn và quy định về việc dự trù danh mục, số lượng hợp lý, sát với mô hình bệnh tật, tuy nhiên các đơn vị vẫn chưa tuân thủ tốt. Điều này cho thấy, cần phải xem xét kỹ danh mục, số lượng dự trù thuốc, phân tích rõ nhu câu sử dụng thực tế của các bênh viện trong khi lập và thẩm định kế hoạch, để không tiếp diễn tình trạng danh mục thuốc trúng thầu 'quá rộng' đối với nhu cầu sử dụng của các bệnh viện.

4.3 Thực hiện kết quả trúng thấu theo gói thâu, nhóm kỹ thuật. Tỷ lệ thực hiện của 03 gói thâu: Gói thầu thuốc Generic $(60,3 \%)$, Gói thầu thuốc biệt dược gốc $(53,4 \%)$, Gói thầu thuốc cổ truyền, thuốc dược liêu $(75,6 \%)$ đều chưa đạt tỷ lệ $80 \%$ theo quy định. Kết quả này thấp hởn tỷ lể thực hiện ở các địa phương khác, ví dụ như ở Hà Giang tỷ lệ thực hiện của 3 gói trên lần lượt là $72,46 \%, 90,62 \%, 55,16 \%$ [3].

Gói thầu thuốc biệt dược gốc có tỳ lệ số khoản thực hiện cao $(89,2 \%)$ nhưng tỷ lệ giá trị thực hiện lại thấp nhất trong 3 gói $(53,4 \%)$ cho thấy các bềnh viên đã có sự cân nhắc khi sử dụng biệt dược, chỉ sử dụng trong những trường hợp cần thiết, tránh làm gia tăng chi phí thuốc trong tình trạng nguồn quỹ bảo hiểm y tế đang thiếu, và phù hợp với chỉ đạo của Chính phủ tại Công văn số 1649/VPCP-KGVX ngày 24/02/2017 của văn phòng chính phủ về việc công tác đấu thầu thuốc tại các cơ sở y tế công lập và văn bản 3794/BHXH-DVT của Bảo hiểm xã hội Viêt Nam.

Gói thầu thuốc cổ truyên, thuốc dược liệu của các bệnh viện tuyên tỉnh có tỷ lệ số khoản thực hiện cao $(77,5 \%)$, đồng thời tỷ lệ giá trị thực hiện cũng cao $(75,6 \%)$. Điều này hợp lý vì số lượng khoản mục và giá trị gói thầu trên rất nhỏ so với tổng danh mục thuốc trúng thầu của các bệnh viên tuyến tỉnh, nhu cầu điêu trị của các thuốc cổ truyên, thuốc dược liệu ở các bệnh viện tuyến tỉnh không có nhiều biến động.

4.4 Cơ cấu số khoản của từng gói thâu, nhóm kỹ thuật theo tỷ lệ thực hiện

Trong 3 gói thầu: Gói thầu thuốc Generic có tỷ lệ số khoản thực hiện không đạt $80 \%$ cao nhất (chiếm 70,6\% tổng số khoản Generic trúng thầu), tiếp theo là Gói thầu thuốc biệt dược gốc $64,9 \%$ và thấp nhất là Gói thầu thuốc cổ truyền, thuốc dược liệu 48,4\%. Tỷ lệ cao gấp đôi so với kết quả thực hiên của Sở Y tế Hà Nôi năm 2016: Gói thầu thuốc Generic có tỷ lệ thực hiện không đạt $80 \%$ là $30,1 \%$, Gói thầu thuốc biệt dược gốc có tỷ lệ thực hiện không đạt $80 \%$ là 35,2\% [4].

Tỷ lê số khoản thực hiên vượt $120 \%$ ở hai Gói thầu thuốc Generic và Gói thầu thuốc biệt dược gốc tương đương nhau $(2,6 \%$ và $2,7 \%)$, Gói thầu thuốc cổ truyền, thuốc dược liệu không có thuốc thực hiên vượt $120 \%$. So với Sở Y tế Hà Nội thì tỷ lệ thực hiện vượt $120 \%$ ở các bệnh viện tuyến tỉnh trền địa bàn tỉnh Vĩnh Phúc tốt hởn: Tai Sở Y tế Hà Nội, Gói thầu thuốc biêt dược gốc có $3 / 58$ (bằng $5 \%$ ) thuốc thức hiện vượt $120 \%$, Gói thầu thuốc Generic có 11/228 (bằng 4,8\%) thuốc thực hiện vượt 120\% [4].

Gói thầu thuốc cố truyền, thuốc dược liệu: là gói thầu có tỷ lệ số khoản thực hiện không đạt $80 \%$ thấp nhất. Gói thầu thuốc cổ truyền, thuổc dược liệu có số khoản và giá trị trúng thâuu thấp, đồng thời nhu câu về các thuốc cổ truyền, thuốc dược liêu của các bênh viên tuyến tỉnh nhỏ, ít có biến động nên việc dự trù sát hơn gói thầu thuốc generic và gói thẩu thuốc biệt dược gốc.

4.5 Phân tích nguyên nhân số khoản thực hiện vượt quá $120 \%$ kết quả trúng thẩu. Tỷ lệ thuốc thực hiện vượt $120 \%$ giá trị trúng thâu không đáng kể, chỉ chiếm 1,9\% tổng số khoản trúng thầu. Việc thực hiện vượt quá $120 \%$ số lương trúng thầu là không đúng quy định theo Thông tư số $11 / 2016 /$ TT-BYT và đây có thể là căn cứ để cơ quan bảo hiểm xã hội xuất toán các thuốc này [1]. Tổng số có 16 thuốc mua vượt $120 \%$, có thuốc vì lý do bất khả kháng, để đảm bảo đủ thuốc phục vụ công tác khám bệnh, chữa bệnh, có thuốc bi phạm quy định khi còn các thuốc tương tự thay thế [2].

Tổng số có 8 thuốc các bệnh viện tuyên tỉnh mua vượt $120 \%$ số lượng trúng thẩu, trong khi vẫn còn các thuốc tương tự trong danh muc trúng thầu thay thế: Cefdinir $125 \mathrm{mg} / 5 \mathrm{ml}$, hốn dịch; Amlodipin 5mg, Nhóm 1; Nhôm oxyd 400mg+ Magnesium hydroxyd $800,4 \mathrm{mg}+$ Simethicone 80mg; Esomeprazol 20mg uống Nhóm 1 (Krka Slovenia); Esomeprazol 40mg Biệt dược; Sucrafat $1 \mathrm{~g} / 5 \mathrm{~g}$; Alverin citrat $60 \mathrm{mg}$ + Simethicon $80 \mathrm{mg}$; Insulin 300UI/3ml Biệt dược. Điều này có thể do các bệnh viện và nhà thâuu trong khi thực hiện kết quả trúng thầu đã sơ suất không giám sát số lượng thực hiện của từng thuốc, dấn đến khi gọi hàng đã gọi quá số lượng cho phép. 
Như vậy cân tăng cường theo dõi, giám sát việc thực hiện kết quả trúng thâu theo đúng quy định tại các bệnh viện tuyến tỉnh, không để tình trạng mua vượt số lượng theo quy định. Có chế tài xử lý đối với các đơn vị vi phạm không do nguyên nhân khách quan.

\section{KẾT LUẬN}

Các bệnh viên tuyến tỉnh trên đia bàn tỉnh Vĩnh Phúc năm 2017 có tỷ lệ thực hiện kết quả trúng thâu thấp, chỉ đạt 59,4\% tổng giá trị trúng thâu. Số khoản không thực hiện chiếm 23,9\% tổng số khoản trúng thâu; $68,8 \%$ số khoản thực hiện không đạt $80 \%$ số lượng trúng thâu. Gói thầu thuốc Generic có tỷ lệ số khoản thực hiện không đạt $80 \%$ cao nhất, chiếm $73,5 \%$ số khoản thực hiện. Trong 16 thuốc thực hiện vượt $120 \%$ có 8 thuốc có nguyên nhân khách quan, bất khả kháng: đã sử dụng hết số lượng trúng thâu, không có thuốc thay thế, hoặc thuốc thay thế cũng đã sử dụng hết số lượng trúng thâu, hoặc thuốc thay thế có thông báo dừng cung ứng của nhà thâu; 8 thuốc thực hiện không đúng quy định khi vẫn còn số lượng thuốc trúng thâu khác thay thế.

\section{TÀI LIÊU THAM KHẢO}

1. Bộ Y tế (2016), Thông tư số 11/2016/TT-BYT ngày 11/05/2016 "Quy định việc đấu thâuu thuốc tại các cở sở y tế công lập".

2. Bộ Y tế (2016), Thông tư số 09/2016/TT-BYT ngày 05/05/2016 "Ban hành danh mục thuốc đấu thâu, danh muc thuốc đấu thầu tâp trung, danh muc thuốc được áp dung hình thức đàm phán giá".

3. Hoàng Quốc Việt (2016), Phân tích thực hiên kết quả đấu thâuu thuốc tại các cớ sở y tế cồng lập tỉnh Hà Giang năm 2016, Luận văn Dược sỹ chuyên khoa I, Trường Đai hoc Dước Hà Nôi.

4. Nguyễn Thị Hồng Hà (2018), Phân tích kết quả và viêcc thực hiện kết quả đấu thầu thuốc tập trung tai Sở Y tế Hà Nội năm 2016, Luận văn Thạc sỹ dược hộc, Trường Đại học Dược Hà Nôi.

5. Nquvễn Thanh Tùnq (2016), Phân tích kết quả trúng thầu thuốc tại Sở Y tế Nam Định năm 2015, Luận văn Thạc sỹ Dược học, Trường đại học Dược Hà Nôi.

6. Lê Thanh Tùng (2014), Phân tích kết quả đấu thầu thuốc tại Sở Y tế tỉnh Yên Bái năm 2014, Luận văn thạc sỹ, Đai học Dược Hà Nội.

7. Lương Thị Thúy Vinh (2017), Phân tích kết quả đấu thâuu thuốc tai Sở Y tế Hà Giang năm 2016, Luận văn Dược sỹ chuyên khoa I, Trường Đại học Dước Hà Nôi

8. Quốc Hội (2013), Luật đấu thâuu số 43/2013/ QH13, ngày 26/11/2013.

\title{
THAY ĐỔI TÌNH TRANG DINH DƯỠ'NG SAU CAN THIÊ̂P TRÊN BỆNH NHẦN UNG THƯ LƯỡ'I, SÀN MIỆNG
}

\author{
Hoàng Việt Bách ${ }^{1}$, Nguyễn Thị Thuý ${ }^{2}$ Trần Thị Thuỹ², \\ Ngô Quốc Duy ${ }^{1}$, Ngô Xuân Quý1, Phạ Văn Giao', \\ Lê Văn Quảng', Lê Thị Hương
}

\section{TÓM TẮT}

Mục tiêu: Đánh giá hiệu quả can thiệp dinh dưỡng của các bệnh nhân ung thư khoang miệng qua chỉ số nhân trắc và các triệu chứng lâm sàng. Phương pháp nghiên cứu: Nghiên cứu can thiệp trên 34 bệnh nhân ung thư lưỡi và sàn miệng trong vòng 2 tháng từ thời điểm phẫu thuật và theo dõi tình trạng dinh dưỡng, các triệu chứng lâm sàng qua các mốc thời gian. Kết quả: Sau can thiêp nguy cơ suy dinh dưỡng của bệnh nhân giảm đáng kể từ $73 \%$ còn 52,94\%, cân nặng có sự cải thiện, nhiều triệu chứng liên quan tới tiểu hóa cũng được đánh giá có sự thay đổi tích cực như: cảm giác ngon miệng, táo bón, tiêu

\footnotetext{
${ }^{1}$ Bệnh viện $K$

${ }^{2}$ Trường đại học y Hà Nội

Chiu trách nhiệm chính: Hoàng Việt Bách

Email: hoangvietbach90@gmail.com

Ngày nhận bài: 7.01.2021

Ngày phản biện khoa học: 8.3.2021

Ngày duyệt bài: 15.3.2021
}

chảy... Kết luận: Nghiên cứu can thiệp dinh dưỡng trên đối tượng bênh nhân ung thư lưỡi và sàn miệng đã cho thấy hiệu quả tích cực đối với cải thiện về tình trạng dinh dưỡng qua chỉ số nhân trắc và các triệu chứng lâm sàng của người bệnh.

Tư khoá: ung thư lưỡi, sàn miệng, can thiệp dinh dưỡng, tình trạng dinh dưỡng

\section{SUMMARY \\ CHANGES OF NUTRITIONAL STATUS AFTER NUTRITIONAL INTERVENTION IN PATIENTS WITH ORAL CANCER}

Purpose: to evaluate the effectiveness of nutritional intervention in oral cancer patients by anthropometric index and clinical symptoms.Patients and methods: Nutritional intervention study on 34 patients with oral cancer within 2 months from the time of surgery and monitoring the nutritional status as well as clinical symptoms over time. Results: After the intervention, the patients' risk of malnutrition decreased significantly from $73 \%$ to $52.94 \%$, their weights were improved, and many digestive symptoms 